\title{
Dynamics of Sahelian Pastures in Relation to Drought and Grazing*
}

\author{
H. Breman** \\ Asscociated Expert of UNESCO at the "Centre Pedagogique Superieur", Bamako, Mali
}

A.M. Cissé

"Ecole Normale Supérieure", Bamako, Mali

\begin{abstract}
Summary. The dynamics of the vegetation were studied in the transition zone from the savannah to the Sahel in order to distinguish between the influence of the recent drought and the influence of overgrazing on the natural rangelands. The drought affected especially the different plant species at the northern limit of their habitat. It is, however, not well possible to speak of a sahelisation of the savannah, since the species in regression were replaced by invaders, like Borreria spp, and not by true Sahelian species. An exception was Blepharis linariifolia, which moved to the south. Grazing affected good fodder grasses like Andropogon gay'anus, which were replaced by a legume with a short growth cycle, Zornia glochidiata, and an unpalatable annual grass Elionurus elegans. The species much stimulated by the drought, Borreria spp. and Blepharis linariffolia, did not occur in the intensively grazed pastures.
\end{abstract}

\section{1, Introduction}

In general terms much has been written about the deterioration of the environment in the Sahel, the region just at the southern border of the Sahara. The desertification of these shrub grasslands, grazed by millions and millions of cattle, goats and sheep, is feared by many. especially since the last drought (c.f. Rapp, 1974).

Most authors agree that desertification is partially, if not mostly, of human origin (Boudet, 1972: Cloudsley-Thompson, 1974; Grove. 1973). It is, however, rather difficult to qualify and to quantify the human and the climatic effects on the environment. since they are generally mixed. Moreover, it should be

* The work was carried out with the assistance of M.M.A. Djittye and A. Sow, Centre National de Recherche Zootechnique "Sotuba". N. Diarra. Ecole Normale Supérieure, M. Togola, Station du Sahel, and M.I. Cissé, A. Diallo. L. Diarra, M. Sidibé, G. Traoré. Centre Pédagogique Supérieur ** Present address and atdress for offprint requests: C.A.B.O., P.O. Box 14, Wageningen, the Netherlands 


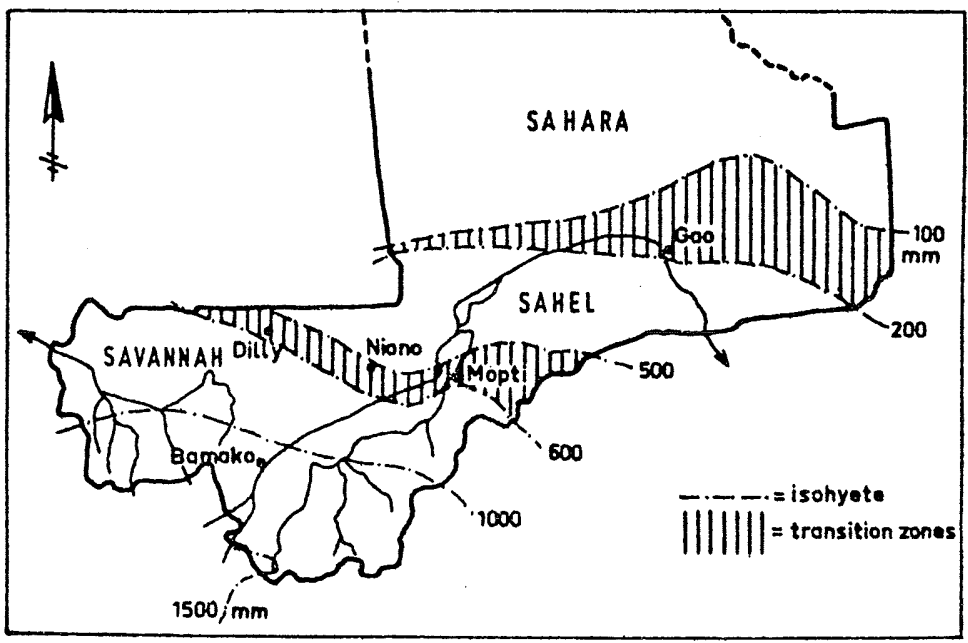

Fig. 1. Climate zones of Mali (West-Africa)

realised that not every change of the vegetation during some years of drought means desertification and not every transformation of the vegetation by grazing means degradation (Valenza, 1975).

The underlying study describes the dynamics of the vegetation at the "Nionoranch", a protected area $350 \mathrm{~km}$ north-east of Bamako (Mali), in the transition zone from the savannah to the Sahel (Fig. 1). Since its foundation in 1960 the ranch has only been partly exploited, around the single permanent drinkingpoint that exists. The vegetation had been described just before the serious drought, with respect to mapping, the composition and the productivity of the different vegetation types (Boudet, 1970). Therefore the ranch offered a unique chance to distinguish between the pure influence of climatic fluctuations, far from the water, and the effect of cattle and drought, in the overgrazed areas near the drinking point.

A first attempt at such an analysis showed important changes in the species composition and the productivity of the ranch land, since the beginning of the drought (Togola et al., 1975).

\section{Site Description}

The Niono region is part of the old Central Delta of the Niger, which was flooded year after year by the river during and immediately after the wet season. The soils are from alluvial origin, modulated by the wind in the form of sand dunes in certain parts, while elsewhere there are still plains with mainly loam soils (Davey, 1957).

The ranch, which covers 11,000 ha, is situated at $14^{\circ} 20^{\prime} \mathrm{N}$ and $5^{\circ} 50^{\prime} \mathrm{W}$, at an altitude of almost $300 \mathrm{~m}$. The climate of the region is dry-tropical of the sahelo-soudanian type, with a single rainy season from June until September. 
Fig. 2. Rainfall variations in Niono (following Cissé, 1976)

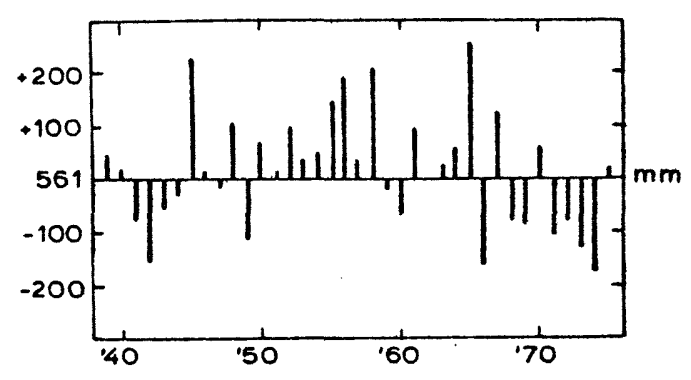

The main annual rainfall is about $570 \mathrm{~mm}$ with a standard deviation of $120 \mathrm{~mm}$. Figure 2, which presents the variation in rainfall since the beginning of the observations in 1939, shows two concentrations of dry years: at the beginning of the forties and from the end of the sixties until 1974. From 1970 until 1974 the drought was very accentuated with a mean rainfall of $390 \mathrm{~mm}$ in 34 days against $570 \mathrm{~mm}$ in 50 days normally.

The mean monthly temperature is the lowest in January $\left(25.8^{\circ} \mathrm{C}\right)$ and the highest in May $\left(34.7^{\circ} \mathrm{C}\right)$; there is a second minimum during the rainy season, in August $\left(27.8^{\circ} \mathrm{C}\right)$ and a second maximum in October $\left(29.2^{\circ} \mathrm{C}\right)$. The potential evapotranspiration is about $1700 \mathrm{~mm}$ a year.

The vegetation in the Niono region is characteristic for the transition zone between the Sahel and the soudanese savannah according to several authors (Boudet, 1970). On the ranch 3 main vegetation types are distinguished:

A) Clay depressions and the large loamy plains are characterized by the legume tree Pterocarpus lucens, sometimes as isolated individuals with other woody species in a relatively open savannah, but on other places forming actual forests.

$\left(a_{2}\right)$ The rather flat sand dunes are more open than the previous vegetation type; Schoenefeldia gracilis is their most important grass.

B) Depressions and valleys between the sand dunes have a true savannah character, with their tall perennial grass Andropogon gayanus.

On the ranch Boudet (1970) separated these 3 vegetation types into 8 subtypes, from which the 3 most important, $\mathrm{A}_{3}, \mathrm{~A}_{4}$ and $\mathrm{Ca}_{2}$, are studied (see Tables 1 and 3 for their species composition, as described by Boudet). These 3 sub-types together cover 8,340 out of 11,000 ha, when they were studied in 1969. Two of them, $A_{3}$ and $A_{4}$ have a rather loamy substrate and the soils of $\mathrm{Ca}_{2}$ consist for $80 \%$ out of sand. Their distribution is shown by Figure 3.

\section{Methods}

The species composition and the percentage coverage were studied in September at the end of the growing season, at 7,8 and 11 sites for the vegetation types $A_{4}, A_{3}$ and $\mathrm{Ca}_{2}$ respectively. Per site a mean number of 3 vegetation strips were analysed in detail (see below).

The standing crop of herbs was estimated mid-November at 5,7 and 14 different sites for $\mathrm{Ca}_{2}, \mathrm{~A}_{3}$ and $\mathrm{A}_{4}$ respectively, on a total of 75,108 and 260 separate $\mathrm{m}^{2}$ (see below).

A distinction between the observations in the area with high animal pressure within $4 \mathrm{~km}$ of the permanent drinking point and the area almost untouched by cattle farther than $4 \mathrm{~km}$ from 


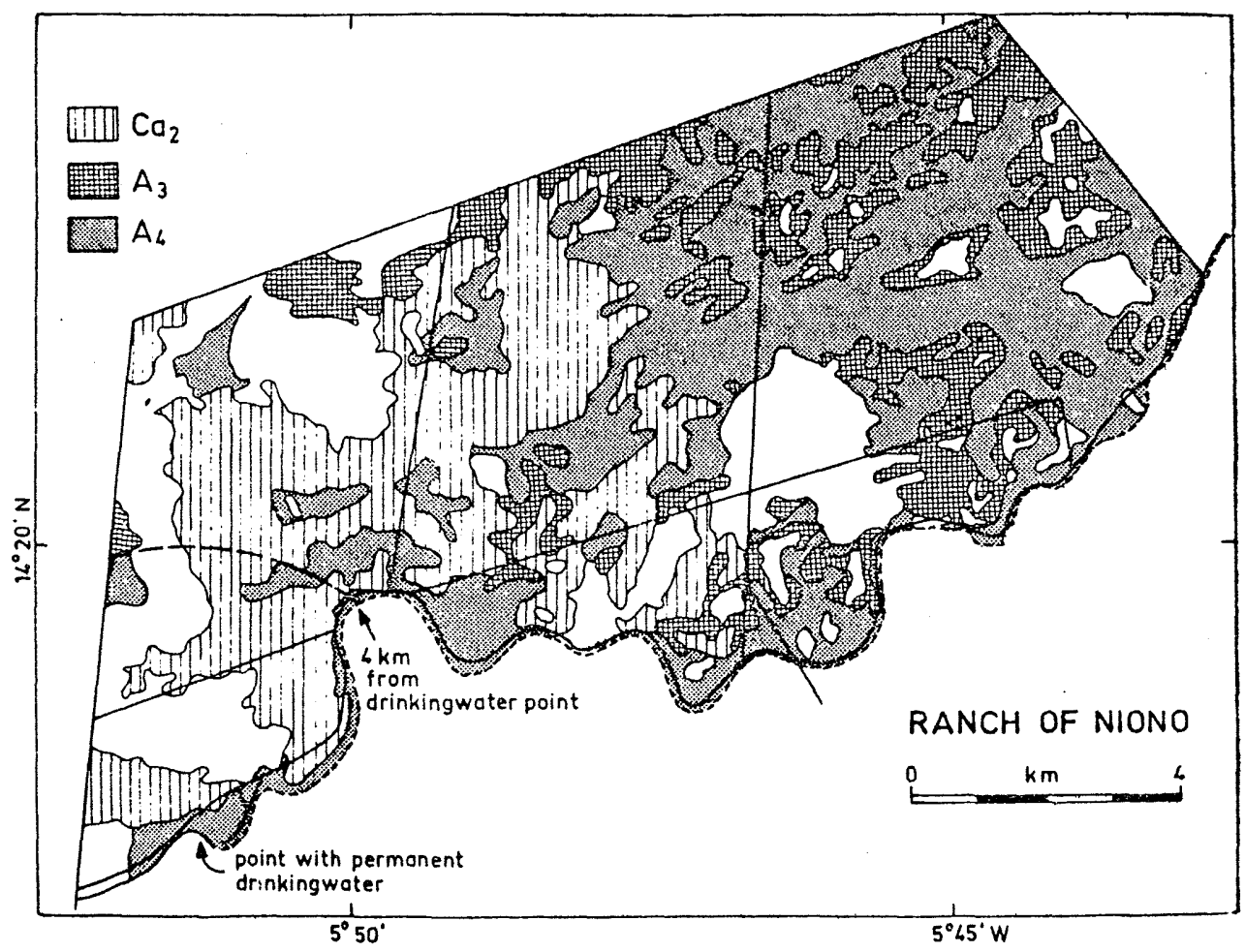

Fig. 3. The vegetation distribution of the Niono-ranch

the water is made only for $\mathrm{Ca}_{2}$ and $\mathrm{A}_{4}$ (Fig. 3). In these cases weighted means in relation to the surfaces were calculated for the vegetation types $\mathrm{Ca}_{2}$ and $\mathrm{A}_{4}$ as a whole; about $5 \%$ of $\mathrm{A}_{4}$ and $20 \%$ of $\mathrm{Ca}_{2}$ were under high pressure of cattle. $\mathrm{A}_{3}$ is found only far from the water, so that the influence of grazing could not be studied here.

\subsection{Soil Cover}

The percentage coverage by herbs at the end of the growing season was measured estimating the surface of the vertical projection of the vegetation in relation to the total surface of the mentioned strips of $10 \times 0.1 \mathrm{~m}$.

In so far as the woody species are concerned, their number per hectare was first estimated per species by counting them in the same, but now enlarged strips $(50 \times 4 \mathrm{~m})$. They were counted individually, when an effect on the herb layer was to be expected, which means in practice that they had to be higher than $0.5-1 \mathrm{~m}$. After this the mean surface of the crown projection on the soil surface was estimated and for each species this figure was multiplied by the number per hectare to find the soil cover per species. The sum of these covers per species is presented as the total percentage of the soil covered by woody species.

\subsection{Species Composition}

The methodology described by Boudet (1970) was used to be able to compare the results of our study with those obtained in 1969 by Boudet. Per site studied the following code indicating 
the abundancy and frequency per species was used:

+ species present as isolated individuals,

1 species rather rare,

2 species abundant, but coverage less than $5 \%$,

3 species abundant, coverage $5-50 \%$,

4 and 5 as 3 , but coverage $50-75 \%$ and over $75 \%$, respectively.

To describe each vegetation type as a whole, a mean code was determined based on the abundance and frequency of the species per site studied.

When a species is found in less than $25 \%$ of the sites studied, it is considered accidental and the species will not be mentioned for the vegetation type in question, unless this species is very abundant in certain sites which will be indicated by the sign! Species found in $25-50 \%$ of the sites are coded $-r$-, however, when they are abundant in $25-30 \%$ of the sites, the code changes into $-x$-. When species are present in over $50 \%$ of the sites of a certain vegetation type studied. the codes $+, 1,2,3,4,5$ are used; these codes being the mean of those of the individual sites in which the species are present. When a certain species is limited to special places the code is followed by the sign! The sign! $!^{\circ}$ is used for species of the shadow.

3.2.1. Herbs. For herbs each site is described by an analysis of 2-4 transects or strips of $10 \mathrm{~m}$ long and $0.1 \mathrm{~m}$ wide. For each running meter the presence of a species was noted; on each 6th meter the total number of individuals of each species was counted and the coverage per species estimated.

The code described is subjective with respect to,+ 1 and 2 . In the present study they were interpreted as follows: for species present in over $50 \%$ of the sites with a coverage below $5 \%$, the mean number of individuals in the 6th meter was multiplied by the mean number of meters in which the species was observed (per transect). The code + was used when this figure was below 5 (species present as isolated individuals), 1 for 5-15 (rather rare) and 2 for figures higher than 15 (abundant). Evidently, in these cases an absolute comparison with the descrition by Boudet (1970) is impossible.

3.2.2. Woody Species. The code had to be interpreted also for woody species. The code + was used for one individual only per strip of $50 \times 4 \mathrm{~m}, 1$ for 2 or 3 individuals and 2 for 4 or more individuals of a certain species per transect. This means for the code,+ 1 and 2 , less than 50,50 to 150 , and over 150 individuals per ha, respectively.

\subsection{Standing Crop}

The productivity of the vegetations studied was measured as the standing crop of herbs at the beginning of the dry season; the herbs were cut at a height of 0 to $2 \mathrm{~cm}$ and attempts were made at collecting the fallen seeds if present. At each site $15 \mathrm{~m}^{2}$ or more, chosen at random, were separately harvested and directly weighed ("green weight"). The samples of one site were dried together to determine the "dry weight", the mean biomass in $\mathrm{g} / \mathrm{m}^{2}$. The "green weight" of the individual square meters was used to calculate the standard deviation and the confidence interval of the mean. Expressed as a percentage of the mean "green weight", this confidence interval was used for the "dry weight" as well.

\section{Results}

\subsection{Soil Cover}

The estimation of soil cover, especially for herbs, is rather subjective and is much dependent on the individual interpretation of the observations, the time of observation and the development of the vegetation. We do not consider our figures, therefore, directly comparable to those published by Boudet (1970). Yet, the information about the influence of drought and grazing can still be obtained by comparing the differences between the vegetations studied. 
4.1.1. Herbs. Before the drought Boudet (1970) found an important difference between $A_{3}$ on the one hand and $A_{4}$ and $\mathrm{Ca}_{2}$ on the other hand, viz. a soil cover of $20 \%$ only for $A_{3}$, but one of $50 \%$ and $40 \%$ for $A_{4}$ and $\mathrm{Ca}_{2}$. The difference in 1975 was not significant: $A_{3}$ was again about $20 \%$ and both other sub-types about $25 \%$.

Grazing decreased the coverage on the loamy soils of $\mathrm{A}_{4}$ to about half of that of the area without animal pressure. For the sand dunes of $\mathrm{Ca}_{2}$ no difference was found between the soil cover within a radius of $4 \mathrm{~km}$ from the drinking point and that of the pastures more than $4 \mathrm{~km}$ away from the water.

4.1.2. Woody Species. With the woody species an important difference was detected between the results of 1975 and the figures presented by Boudet (1970). He mentions a coverage of $25 \%$ for $\mathrm{A}_{4}$ and only $5 \%$ for both other vegetation types, our coverage of $\mathrm{A}_{4}$ and $\mathrm{Ca}_{2}$ was about $25 \%$ and that of $\mathrm{A}_{3}$ even $10 \%$ more. The difference does not reflect the effect of drought, but was the result of protecting the area. Boudet (1970) described the Niono area on the base of aerial photos from 1952, so 8 years before the ranch was created. We had new photos at our disposal from 1975 and they show the increase of scrubs and trees on the ranch. The cover of woody species in the surroundings is still poor.

People who are acquainted with the Niono ranch will wonder how the cover of $\mathrm{A}_{4}$ and the more open vegetation $\mathrm{Ca}_{2}$ could be the same. The impression of a more open vegetation with regard to the scrubs and trees reflects the reality, the coverage of the dunes being only $17 \%$, but that of the valleys almost $30 \%$. The total number of individual scrubs and trees per ha was 120 on the dunes and 440 in the valleys. The mean figure obtained for $\mathrm{Ca}_{2}$ is $290 /$ ha, for $A_{3}$ and $A_{4} 395$ and $270 /$ ha, respectively.

The drought had killed many trees and scrubs, especially Pterocarpus lucens, Guiera senegalensis, Bombax costatum and Acacia seyal were affected since 1973 (Togola et al., 1975). Although termite activity had already destroyed many dead individuals, we observed that $14 \%$ of the scrubs and trees were dead in $A_{3}$, and $4 \%$ in both $A_{4}$ and $\mathrm{Ca}_{2}$.

For woody species the difference was also studied between the pastures near the drinking-point (high exploitation intensity) and those far away from the water. In both cases the vegetation was twice as open under intense grazing and trampling than without or under light exploitation (12-15\% coverage against $24-28 \%$ ). Direct human activity may be an explanation too. The number of individuals of $\mathrm{Ca}_{2}$ is the highest near the drinking point (365/ha against 275/ha). Two thirds of these, however, are the rather small Guiera senegalensis, a scrub which follows man in all his activities in this region. The difference found for the number of individuals of $\mathrm{A}_{4}$ is small, 225/ha near the water against. $270 /$ ha further away.

Trampling seems to be a cause of mortality near the water, since at the ranch Pterocarpus lucens started to die near the drinking point already in 1973, one or two years earlier than away from the water (Togola et al., 1975). 


\subsection{Vegetation Composition}

Visiting the ranch last year, it was almost impossible to recognize the vegetation types distinguished by Boudet (1970), especially due to the changes in the herb layer.

4.2.1. Herbs. The changes in the floristic composition since 1969, is shown in Table 1. Only those species are included which were mentioned in the synoptic list of Boudet (1970) or which were present in 1975, in at least one of the 3 vegetation types, in more than $50 \%$ of the sides studied. Species present in only $25-50 \%$ of the sites were generally so limited in number that it is doubtful on a statistical base to call attention to their presence. Exceptions are Cenchrus bifloris and Sporobolus granularis in $\mathrm{Ca}_{2}$ and Digitaria gayana in $\mathrm{Ca}_{2}$ and $\mathrm{A}_{4}$, which were not mentioned by Boudet for 1969, but were found in such numbers in $25-50 \%$ of the sites in 1975 that they can not be neglected.

The order in which the species are presented in Table 1 is one of the most negatively influenced species, via those not or hardly affected to the plants showing the most positive effect.

Considering the character and the habitat of the different species (Boudet, $1970,1975)$, the drought effect is generally not difficult to understand. The species whose relative importance decreased since 1969, are in Niono at the northern limit of their habitat, the soudanien savannah (the annual grasses Andropogon pseudapricus, Chloris prieurii, Diheteropogon hagerupii, Pennisetum pedicellatum and $P$. subangustum, the legumes Cassia mimosoides and Indigofera prieureana, and the creeping Ipomoea coscinosperma). Both Pennisetum-species are known to live under relatively dry conditions only in the shadow of scrubs and trees. Andropogon gayanus, a tall perennial grass, indeed occurs even in the true Sahel, but only there where water is accumulated by the substrate. An increase is found in the species preferring sand as a substrate, even there where they grow on the loamy sands of $\mathrm{A}_{3}$ and $\mathrm{A}_{4}$. With the exception of Microchloa indica, which even occurs on squelettic soils in the southern savannah, they are species of the Sahel and the transition zone from the Sahel to the savannah (the annual grass Aristida mutabilis and the Acanthacae Blepharis linariifolia). The invading species from fallow land, three Borreria species and Eragrostis tremula, were also stimulated.

To study the effect of grazing on the absolute and on the relative importance of the different species, a comparison was made between the mean number of individuals per species per $\mathrm{m}^{2}$ far from the drinking point and in its neighbourhood (Table 2). The difference in floristic composition is very important. In $\mathrm{A}_{4}$ as well as in $\mathrm{Ca}_{2}$ Zornia glochidiata, the well known legume of overgrazed land, is dominant near the drinking point (Boudet, 1975), and also Elionurus elegans, an unpalatable annual grass. Microchloa indica seems to be stimulated by grazing in $\mathrm{A}_{4}$, while Schoenefeldia gracilis is a rather important element in $\mathrm{Ca}_{2}$, not affected by grazing. 
Table 1. Synoptic list of herbs represented in the three most extended vegetation types in 1969 and 1975, showing the influence of drought

\begin{tabular}{|c|c|c|c|c|c|c|}
\hline \multirow[t]{2}{*}{ Species } & \multicolumn{2}{|l|}{$\mathrm{A}_{3}$} & \multicolumn{2}{|l|}{$\mathrm{A}_{4}$} & \multicolumn{2}{|l|}{$\mathrm{Ca}_{2}$} \\
\hline & 1969 & 1975 & 1969 & 1975 & 1969 & 1975 \\
\hline Andropogon gavanus & - & - & 3 & - & 1 & - \\
\hline Diheteropogon hagerupii & 1 & 1 & 3 & 1 & 3 & 1 \\
\hline Indigofira prieureana & - & - & 2 & - & 2 & - \\
\hline Pennisetum pedicellatum & - & - & $2 !^{\circ}$ & - & $2 !^{\circ}$ & - \\
\hline Pennisetum subangustum & - & - & $!^{\circ}$ & - & $3 !^{\circ}$ & - \\
\hline Andropogon pseudapricus & 1 & - & 1 & - & 1 & - \\
\hline Cassia mimosoïdea & - & - & 1 & - & 2 & $\mathbf{r}$ \\
\hline Polycarpaea corymbosa & - & + & 2 & 1 & 2 & - \\
\hline Ipomoea coscinosperma & - & - & 1 & - & 1 & - \\
\hline Chloris prieurii & - & - & - & - & $2 !$ & $r$ \\
\hline Elionurus elegans & - & 1 & 2 & 1 & 3 & 2 \\
\hline Polycarpaea eriantha & $!$ & - & $!$ & - & - & - \\
\hline Schizachirium exile & - & - & - & - & + & - \\
\hline Cochlospermum tinctorium & - & - & - & - & $!$ & - \\
\hline Zornia glochidiata & - & + & - & - & 3 & 2 \\
\hline Loudetia toguensis & 3 & 2 & $!$ & 1 & 1 & 2 \\
\hline Fimbristilis hispidula & - & + & $!$ & - & - & - \\
\hline Monechma ciliatum & + & + & $!^{\circ}$ & - & - & - \\
\hline Schoenefeldia gracilis & 1 & $!$ & $!$ & + & 2 & 3 \\
\hline Blepharis maderaspatensis & - & $1 !^{\circ}$ & - & - & - & - \\
\hline Borreria filifolia & - & $1 !$ & - & - & - & - \\
\hline Mollugo nudicaulis & - & + & - & + & - & - \\
\hline Aristida mutabilis & - & - & - & - & - & 1 \\
\hline Eragrostis tremula & - & - & - & - & - & 1 \\
\hline Digitaria velutina & - & + & - & + & - & $r$ \\
\hline Pandiaka heudelotii & - & + & - & + & - & $\mathbf{r}$ \\
\hline Microchloa indica & - & 1 & - & 1 & - & 1 \\
\hline Commelina forskalaei & - & 1 & - & 1 & - & 1 \\
\hline Borreria stachydea & - & 3 & 2 & 3 & 1 & - \\
\hline Borreria radiata & - & 2 & $!$ & 3 & $i$ & 3 \\
\hline Blepharis linariifolia & - & 2 & - & 2 & + & 3 \\
\hline Borreria chaetocephala & - & 2 & - & 3 & - & 3 \\
\hline
\end{tabular}

For code see 3.2 ; the 2 lines separate the adversely affected species, the species not significantly influenced and those positively influenced

4.2.2. Scrubs and Trees. The abundancy of the different scrubs and trees in 1969 and in 1975 is compared in Table 3 (for comments on the presentation of the synoptic list see 4.2.1.). The list of species could perhaps have been longer if more than the mean $750 \mathrm{~m}^{2}$ could have been analysed per site studied in 1975; we suppose that the following species could have been added with code + : Adansonia digitata, Acacia raddiana and Combretum micranthum for $\mathrm{Ca}_{2}$, Acacia senegal for $\mathrm{Ca}_{2}$ and $\mathrm{A}_{4}$, Combretum aculeatum for $\mathrm{A}_{3}, \mathrm{~A}_{4}$ and $\mathrm{Ca}_{2}$, Dichrostachys cinerea for $\mathrm{A}_{3}$ and Bombax costatum, Boscia angustifolia and Ximenia americana for $\mathrm{A}_{4}$. 
Table 2. The effect of grazing expressed in the number of individuals per herb species per $\mathrm{m}^{2}$ within the neighbourhood and far from the drinking point

\begin{tabular}{|c|c|c|c|c|c|c|c|c|}
\hline \multirow{4}{*}{$\begin{array}{c}\text { Species } \\
\vdots\end{array}$} & \multicolumn{4}{|c|}{$\mathrm{A}_{4}$} & \multicolumn{4}{|c|}{$\mathrm{Ca}_{2}$} \\
\hline & \multicolumn{8}{|c|}{ Distance to the drinking point } \\
\hline & \multicolumn{2}{|c|}{$\vdots<4 \mathrm{~km}$} & \multicolumn{2}{|c|}{$\cdots>4 \mathrm{~km}$} & \multicolumn{2}{|c|}{$<4 \mathrm{~km}$} & \multicolumn{2}{|c|}{$>4 k \mathrm{kr}$} \\
\hline & $N$ & $\%$ & $N$ & $\%$ & $N$ & $\%$ & $\dot{N}$ & $\%$ \\
\hline Borreria chaetocephala & 1 & 1 & $.19 !$ & 36 & 1 & 0 & 44. & 25 \\
\hline Borreria rettitutt & 2 & 1 & 205 & 39 & 3 & 1 & 17 & 9 \\
\hline Blepharis linariifolig & 6 & 3 & 44 & 8 & 2 & 0 & 41 & 33 \\
\hline Borreria siochudea & 0 & 0 & 50 & 10 & 0 & 0 & 4 & 22 \\
\hline Dihecremporem lsugstupii & - & - & 9 & 2 & 1 & 0 & 14 & 8 \\
\hline Schoenefeldig gracilis & 0 & 0 & 1 & 0 & 9.4 & 19 & 40 & 22 \\
\hline Polycarpaea corymbosa & - & - & 4 & 1 & $\frac{1}{-}$ & $\div$ & ${ }_{11}^{14} 0$ & $\because 0$ \\
\hline Cienium olegans. & + & $\dot{L}$ & - & $\therefore$ & $\because$ & $\because$ & 2 & 1 \\
\hline Loudetial ongensis & 0 & 0 & 4 & 1 & 0 & 0 & 2 & 1 \\
\hline Commelinu forskalaei & 3 & 2 & 11 & 2 & 4 & 1 & $i$ & 1 \\
\hline Digiauria gayand & 0 & 0 & -- & - & 3 & j & 0 & 0 \\
\hline Microchlos indis a & 22 & 11 & 3 & $i$ & 5 & 1 & 3 & 2 \\
\hline Elionuruy \&legtms & 95 & 46 & 1 & 0 & 69 & 14 & 9 & 5 \\
\hline Zernia gluchidluta & 76 & 37 & - & - & 292 & 60 & 0 & $\theta$ \\
\hline
\end{tabular}

All figures are rounded to units: only those species are included that attained at least $1 \%$ in one of the columns

As was to be expected over a short period of only 6 years, there is only a clear negative influence of the drought: the decrease in the importance of the first 5 species in Table 3. Three of these species, Bombax costatum, Pterocarpus lucens and Guiera senegalensis were already mentioned (4.1.2.), as species found dead frequently. The same applies to the less abundant Sclerocarya birrea and Ziziphus mauritiana. Besides these species, dead individuals of Acacia seyal are found regularly ( $8 \%$ of the specimens counted). Interesting is that frequently the seriously affected Pterocarpus lucens individuals are not completely dead, which can also be observed in Guiera senegalensis.

On the whole the changes in the herb composition have been much more drastic than those in the woody species.

A distinctly negative effect of grazing was only found for Acacia seyal, one of the most palatable woody species in the region. Within a radius of $4 \mathrm{~km}$ from the drinking point the species represents about $10 \%$ of the total number of scrubs and trees in $\mathrm{A}_{4}$ as well as in $\mathrm{Ca}_{2}$; in the area without intensive grazing this is about $25 \%$. Less significant is the decrease in Grewia bicolor from $10-15 \%$ far from the water to $1-5 \%$ near the drinking point. The stimulation of Guiera senegalensis in the intensively grazed area was noticed already (4.1.2.); they represent here almost 40 and $70 \%$ of the total number of woody plants in $\mathrm{A}_{4}$ and $\mathrm{Ca}_{2}$ respectively; far form the water these figures are only 8 and $15 \%$. 
Table 3. Synoptic list of woody species represented in the 3 most extended vegetation types in 1969 and 1975, showing the influence of drought $: \cdots$

\begin{tabular}{|c|c|c|c|c|c|c|}
\hline \multirow[t]{2}{*}{ Species } & \multicolumn{2}{|l|}{$\mathrm{A}_{3}$} & \multicolumn{2}{|l|}{$\mathrm{A}_{4}$} & \multicolumn{2}{|l|}{$\mathrm{Ca}_{2}$} \\
\hline & 1969 & $\therefore 1975 \ldots$ & 1969 & 1975 & 1969 & 1975 \\
\hline Bombax costatum & + & - - : & 2 & - & + & - \\
\hline Pterociarpus lucens & 2 & $1 \cdots \cdots$ & 2 & $r$ & - & - \\
\hline Sclerocarya hirrea & + & $-\cdots$ & 1 & + & 2 & $\mathrm{r}$ \\
\hline Guiera senegalensis & 1 & $1 \cdots$ & 2 & + & 2 & 1 \\
\hline Ziziphus mauritiana & 1 & $+\therefore$ & 1 & + & 1 & + \\
\hline Balaniles aegyptiaca & - & - & + & - & $i$ & $r$ \\
\hline Acacia seyal & 2 & 3 & 2 & 1 & 2 & $1 \ldots$ \\
\hline Cumbretum ghasalense & - & r $\cdots$ & + & + & 1 & $\mathbf{r}$ \\
\hline Grewia bicolor & + & + & 1 & + & + & + \\
\hline Combretum micranthum & - & + & 1 & $\mathbf{r}$ & - & - \\
\hline Adlansonia digitata & - & - & - & - & + & - \\
\hline Commiphora africana & + & + & + & + & + & + \\
\hline Feretia apodenthera & - & + & - & $\mathrm{r}$ & - & - \\
\hline
\end{tabular}

For code see 3.2 ; the dotted line separates the affected species and those not significantly influenced

\section{4:3: Standing Crop . * :

The standing crop at the beginning of the dry season was used to indicate the productivity of the 3 vegetation types. The mean values in 1975 were 153 , 1.86 and $200 \mathrm{~g} / \mathrm{m}^{2}$ for $\mathrm{A}_{3}, \mathrm{~A}_{4}$ and $\mathrm{Ca}_{2}$ respectively, based on the harvest of

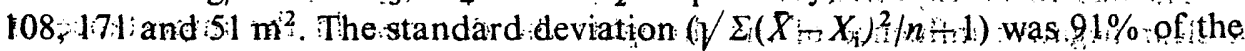
mean for $\mathrm{A}_{3}$ and $\mathrm{A}_{4}$ and $78 \%$ for $\mathrm{Ca}_{2}$, which means that the confidence

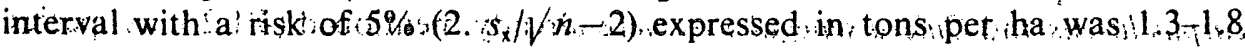
for $\mathrm{A}_{3}, 1,7 \rightarrow 2.1$ for $\mathrm{A}_{4}$ and $1.5 \div 2.5$ for $\mathrm{Ca}_{2}$, This implies an important decrease in productivity: since 1969, for Boudet $(1970)$ found $2 \times 75,4.00$ and 3.00 t/ha for $\mathrm{A}_{3}, \mathrm{~A}_{4}$ and $\mathrm{Ca}_{2}$ respectively during a year of lower rainfall $(474 \mathrm{~mm}$ in 1969 against $568 \mathrm{~mm}$ in 1975 ). These figures still show the adverse effect of drought on the productivity, even during a year of almost normal mainfall: Togola et al. (1975). mention a harvest of $1: 3-1: 8: \mathrm{t} / \mathrm{ha}$, for $A_{4}$ in 1.974 , whereas our figures were somewhat higher (1.7-2.1t/ha in 1975), but 1974: was still a very dry year with only $383 \mathrm{~mm}$ of rainfall $\mathrm{m}$,

Again the influence of grazing was studied by : comparing the standing crop of the theavy exploited area and that of the part of the ranch not used by cattle. The observations in the exploited pastures were done on places not touched by cattle during the growing season; if necessary ; these places ;were protected during one rainy season.

An influence of grazing was demonstrated only in $\mathrm{A}_{4} \approx$ a standing crop of $0.7-1.8 \mathrm{t} /$ ha within a radius of $4 \mathrm{~km}$ from the drinking point against $1.8-2.2$ $\mathrm{t} / \mathrm{ha}$ in the area without intensive grazing. 


\section{Discussion}

The results show that on the Niono ranch it was possible to discriminate between the influence of drought and that of grazing. These effects will be discussed separately.

\subsection{Influence of Drought}

5.1.1. Coverage and Floristic Composition. Generally speaking, the 5 years of severe drought caused a shifting of the sahelo-soudanian vegetation in the direction of a sahelian one. Savannah species and certain species of the transition zone between the savannah and the Sahel disappeared almost entirely or partially, leaving their place open or being replaced by species with a high colonizing capacity - invaders - or by species with a more nothern habitat. The predominant importance of invaders makes it impossible to speak of a real sahelisation.

The space occupied by savannah species seems not to have been used entirely by other species, since the cover of the herb layer decreased from a mean of about $40 \%$ to one of $25 \%$, the mean cover of true sahelian pastures (c.f. 4.1.1. and Boudet, 1970).

The decrease in the coverage of scrubs and trees must have been of a certain importance, in view of the high mortality of some of the woody species. This drought effect is however concealed by the increased density of scrubs and trees due to protecting the ranch. Boudet (1970) only had aerial photos of 1952 at his disposal and probably he used these to estimate the coverage of the woody species; his figures could apply to the unprotected Niono area.

Mortality was high of the woody species Bombax costatum. Pterocarpus lucens and Guiera senegalensis (4.2.2.). The same phenomenon has been observed at several places in the Sahel (c.f. Poupon and Bille, 1975; Diarra, 1976). Togola et al. (1975) showed that the mortality of Bombax was $100 \%$, where the rainfall was below $400 \mathrm{~mm}$ a year during 2 consecutive years; the isohyete of $400 \mathrm{~mm}$ is the extreme northern limit of this tree.

An increase in the density of the northern woody species was not distinctly indicated, unless it was the rather great number of small $(<1 \mathrm{~m})$ Commiphora africana. Many more small individuals occurred, however, of Acacia seyal and Guiera senegalensis, characteristic species of this area.

The change in the floristic composition of the herb layer is certainly the most far reaching (4.2.1.). One cannot speak, however, of a sahelisation proper; although nearly all the savannah species showed an appreciable decline, from the progressing species only one is a sahelian species, Blepharis linariifolia. The 3 other species Borreria chaetocephala, B. stachydea and B. radiata, are invaders with a wide range, growing in the Sahel as well as in the northern savannah.

Blepharis moving to the south has also been observed by Diarra (1976) in the region north of Bamako, and Marty (1975) called attention to the disap- 
pearance of this species from the region north-east of Gao $(100-200 \mathrm{~mm}$ of mean annual rainfall).

Andropogon gayanus is not the only perennial grass affected by the drought. Cymbopogon proximus was similarly influenced in a region north of Niono with $400 \mathrm{~mm}$ of mean annual rainfall, and Marty (1975) observed in the area north-east of Gao that desert species of Panicum replaced Cymbopogon for household purposes.

The disappearance of Pennisetum pedicellatum from $\mathrm{A}_{4}$ and $\mathrm{Ca}_{2}$ (4.2.1.) was noticed also in the Pterocarpus lucens forests on the ranch, where it was the dominant grass before the drought.

The changes observed in the floristic composition of the herb layer will have important consequences for the mapping of Sahelian pastures. It is questionable to use herbs as a criterion in classifying the vegetation types, when the herb composition may change almost completely over some years or even from one year to another. On the ranch, especially in $\mathrm{A}_{3}$, Borreria spp. covered rather wide areas in 1975, where straw indicated a cover of Loudetia togoensis with some Diheteropogon hagerupii in 1974; on $\mathrm{A}_{4}$ Loudetia togoensis was also less abundant in 1975 than in 1974 (Togola et al., 1975), while straw indicated that the same was true for Indigofera prieureana. Comparable indications of far-going changes from one year to another were collected elsewhere in Mali. In the grass verges of the long road from Bamako to Mopti Loudetia togoensis was the dominant species from 1972 to 1974, but in $1975^{\circ}$ Andropogon pseudapricus had grown to be an important component as well. The sand dunes west of Dilly (a village north of Bamako with about $500 \mathrm{~mm}$ of mean annual rainfall) were dominated by Aristida spp. in 1974, but in 1975 they were rare and Eragrostis tremula dominated everywhere (Diarra, 1976).

It will be clear that for future studies of the Sahelian pastures the dynamics of the vegetation has to be an important subject, or "qu'il importe de connaitre, avec, exactitude, l'évolution possible des types de pâturages inventoriés" (Boudet, 1975).

5.1.2. Nutritive Value and Standing Crop. It is shown that 2 aspects determining the value of a vegetation as a pasture are considerably influenced by the drought, namely the floristic composition and the standing crop (4.2. and 4.3.). This affects the quality of the pasture and the quantity of feed available to the cattle.

There is insufficient information to establish, if the replacement of Andropogon gayanus, A. pseudapricus, Diheteropogon hagerupii and Pennisetum pedicellatum by Borreria spp. and Blepharis lineariifolia means an important change in the nutritive value of the pastures in question. For this it will be necessary to analyse the nitrogen content and the digestibility throughout the year. But the palatability of the Borreria is much less than that of the grasses, and Blepharis lineariifolia grows woody with prickly inflorescens after flowering. The high mortality of the very palatable legume tree Pterocarpus lucens is another negative drought effect on the value of the pastures studied.

Boudet (1970) determined on the ranch a mean standing crop of $3.4 \mathrm{t} / \mathrm{ha}$, in 1975 this was only $1.8 \mathrm{t} /$ ha with an even higher rainfall (4.3.). It may be 
wondered whether this is caused by the change in species composition or by another independent factor. The authors tend towards the latter idea: Research in the Negev Desert in Israel made clear that even under very dry conditions the primary production is often limited by nitrogen availability and not directly by rainfall (de Wit, 1975). That this is also true under Sahelian conditions is indicated by the stimulation of the grass production from 2 to $5 \mathrm{t} /$ ha with $\mathrm{N}$-fertilizer under about $500 \mathrm{~mm}$ of rainfall in Niono and Dilly (Cissé, 1976; Diarra, personal communication). We think that due to years of very hot dry weather the balance between the natural supply of nitrogen and the losses shifted to a level of a lower rainfall area. One year of almost normal rainfall (1975) could not restore the former situation completely and less nitrogen available means a lower primary production.

It is worthwhile to notice that the observed production of $1.8 \mathrm{t} /$ ha seems to be almost normal under the rainfall conditions of Niono, while the figure of $3.4 \mathrm{t} / \mathrm{ha}$ (Boudet, 1970) is much too high, according to the relation between productivity and rainfall after Breman (1975). It has to be realized, however, that with regard to the ranch, it is better to speak of standing crop than of production, since it concerns almost unused pastures. We suppose that during years with normal rainfall the availability of nitrogen has a tendency to increase there where the vegetation is not used. This explains the figures of 3 or locally $5 \mathrm{t} / \mathrm{ha}$ (Boudet, 1970) even in 1974 (Cissé, 1976), whereas under the same mean rainfall in the intensively exploited 5th and 6 th region only $2 \mathrm{t} / \mathrm{ha}$ were determined (Breman, 1975).

Anyhow, using the criteria of Boudet (1970) we may conclude that the theoretic carrying capacity of the ranch in 1975 was almost half of those calculated on the basis of the standing crop found in 1969.

\subsection{Influence of Grazing}

The influence of grazing on Sahelian pastures is a better known phenomenon than the effect of drought (c.f. Boudet, 1975; Valenza, 1975). On the ranch we observed an appreciable stimulation of the legume with a short growth cycle, Zornia glochidiata, of the unpalatable annual grass Elionurus elegans and the very small annual grass Microchloa indica (4.2.1.).

The disappearance of good fodder grasses as the perennial grass Andropogon gayanus due to drought is more obvious near the drinking point. No tussocks were left here, while further away from the water some could be found in microdepressions. The regression of such a tall and dominating grass of the savannah is certainly one of the most striking effects of drought and grazing, and it is frequently suggested that pastures should be regenerated by sowing this fodder grass. It should be taken into account, however, that this grass does not tolerate grazing under Sahelian rainfall conditions. Cissé (1976) showed that the quality of Andropogon gayanus as a fodder grass could only be kept at an acceptable level by a 4-week-rotation scheme, but the tussocks were killed by this treatment. Diallo (1976) gave data that this grass formes an important mobile sink of nitrogen, which is present in the roots during the dry season 


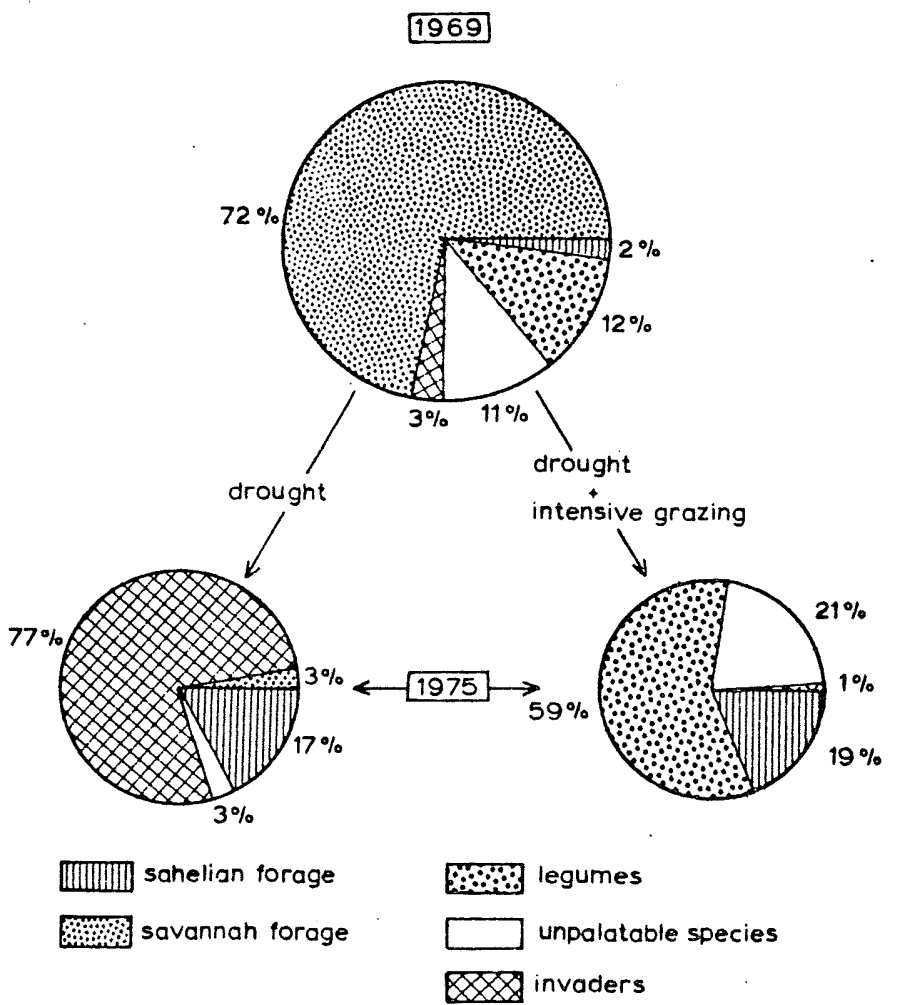

Fig. 4. The influence of drought and grazing on the herb layer of a pasture in the transition zone from savannah to Sahel

and in the above-ground parts during the growing season. Presumably, the plant depends, therefore, only partially on the nitrogen available in the soil, whereas the standing crop grows more and more important every year due to the increasing nitrogen sink. This could be an explanation of both the drought and the grazing effect, since the whole nitrogen supply can be "lost" by the cattle consuming all the young leaves at the beginning of the rainy season, when the nitrogen is mobilized, while during the drought the plant wastes too much water by growing without the inhibiton of limited nitrogen like other sahelian plants.

Andropogon gayanus may be very important, however, as one of the rare sources of green protein rich food during the dry season, since it produces a limited number of young sprouts, especially after it has been stimulated by fire. In this case the grass should be protected against grazing during the rainy season, while the straw of the surrounding annual grasses should be protected against the fire! This function of Andropogon gayanus seems to be essential, in view of the very poor quality of the straw of annuals as a source of protein and the sensitivity to grazing of the other source of protein during the dry season, such woody species as Acacia seyal. As has been mentioned (4.2.2.) this scrub is adversely affected by grazing. To the management of the Sahelian 
pastures in the future the intensity with which this and other woody species may be grazed, is of great interest.

The herb species Borreria spp. and Blepharis lineariifolia, taking full advantage of the drought, did not attain dominance in the intensively grazed pastures (4.2.1.). This effect seems to be brought about by the cattle, since these Borreria spp. were appreciably stimulated in a field of Andropogon gayanus in which the herbage was cut (Cissé, 1976).

In conclusion an attempt was made in Figure 4 to demonstrate the way in which drought alone, and drought and intensive grazing together affected the pasture studied. Vegetation type $A_{3}$ was left out of the scheme, since the influence of grazing could not be studied on it. The situation shown for 1969 is an interpretation of the authors of Boudet's information (1970).

\section{References}

Boudet, G.: Etude agrostologique pour la création d'une station d'embouche dans la region de Niono. Etude agrostologique no. 29, I.E.M.V.T., Paris (1970)

Boudet, G.: Désertification de l'Afrique tropicale. Adansonia 2, 505-524 (1972)

Boudet, G.: Manuel sur les Pâturages tropicaux et les Cultures fourragères. I.E.M.V.T., Ministère de la Coopération, Paris (1975)

Breman, H.: La capacité de charge maximale des pâturages maliens. I.L.C.A. seminar on the evaluation and mapping of African rangelands, Bamako (1975)

Cissé, M.I.: Influence de l'Exploitation sur la Qualité d'un Pâturage Soudano-Sahélien. Thèse au Centre Pédagogique Supérier (Ecole Normale Supérieure), Bamako (1976)

Cloudsley-Thompson, J.L.: The expanding Sahara. Environmental Conservation 1, 5-14 (1974)

Davey, J.T.: The African Migratory Locust in the Central Niger Delta. Part 1. Climate and vegetation. Locusta 5, O.I.C.M.A. (1957)

Diallo. A.: Verification de l'utilisation de l'azote par Andropogon gayanus. Mémoire de D.E.A. au Centre Pédagogique Supérieur (Ecole Normale Supérieure), Bamako (1976)

Diarra, L.: Composition floristique et productivité des pâturages soudano-sahéliens sous une pluviosité annuelle moyenne de 1100 à $400 \mathrm{~mm}$. Thèse au Centre Pèdagogique Supérieur (Ecole Normale Supérieure), Bamko (1976)

Grove, A.T.: Desertification in the African environment. Symposium Drought in Africa, School of Oriental and African Studies, London (1973)

Marty, L.A.: Contribution à la relance des coopératives d’éleveurs en 6e région (Rép. du Mali), C.I.L.S.S./A.D. (F.A.O.) (1975)

Poupon, H., Bille, J.C.: Recherches écologiques sur une savane sahelienne du Ferlo septentrional, Senegal, Influence de la secheresse de l'annee 1972-1973 sur la strate ligneuse. La Terre et la Vie 28, pp. 49-75 (1974)

Rapp, A.: A review of desertification in Africa - water, vegetation and man. Secr. for Intern. Ecology. Sweden (1974)

Togola, M.. Cissé, M.I., Breman, H.: Evolution de la végétation du ranche de Niono depuis 1969. I.L.C.A. seminar on the evaluation and mapping of African rangelands, Bamako (1975)

Valenza, $\mathbf{J}$.: Les pâturages naturels de la zône sylvopastorale du Sahel séneglais vingt ans après leur mise en valeur. I.L.C.A. seminar on the evaluation and mapping of African rangelands, Bamako (1975)

Wit, C.T. de: Studies on actual and potential herbage production in arid regions. I.L.C.A. seminar on the evaluation and mapping of African rangelands, Bamako (1975) 
